\title{
Report on "2020 Academic Camp in Oshu City" Online tour : Research meeting in the age of COVID-19 pandemic
}

\author{
小川歩美 ${ }^{1 *}$, 堀井美里 ${ }^{1}$, 堀井洋 ${ }^{1}$, 川邊咲子 ${ }^{2}$, 後藤真 ${ }^{2}$, 高田良宏 ${ }^{3}$ \\ Ayumi OGAWA ${ }^{1 *}$, Misato HORII ${ }^{1}$, Hiroshi HORII', Sakiko KAWABE ${ }^{2}$, \\ Makoto GOTO ${ }^{2}$, Yoshihiro TAKATA ${ }^{3}$ \\ ₹285-8502 千葉県佐倉市城内町117 \\ 干921-8147 石川県金沢市大額2-44 N3ビル203 \\ 3 金沢大学 Kanazawa University \\ 干920-1192 石川県金沢市角間町 \\ *連絡先著者 Corresponding Author
}

1 合同会社AMANE AMANE.LLC

E-mail: oguchi@amane-project.jp

2 国立歴史民俗博物館

National Museum of Japanese History

コロナ禍においては, 研究者が集まる学会やシンポジウムなどの学術イベントは現地開催が困難な 状況にあり, オンライン上での試みが多く行われている. オンラインの学術イベントについては, 感染 リスクが低い状況で参加できること, さらにこれまで空間的・時間的制約により参加が困難であった参 加者との議論が可能になったことが利点として挙げられる. 一方で, 直接交流し, 体験することで行 っていた課題・現状の共有や議論をどう行うかが課題となっている.

発表者らは, 地域の学術資料の保存・継承・利活用について多面的かつ学際的な議論をする「学 術野営2020 in 奥州市」を2020年7月10日 (土)・11日 (日)にオンラインで開催した. 本発表では, 学 術野営2020における「オンライン巡見」を中心に, 遠隔で参加者同士が課題や現状を共有し議論を 行う学術イベントの実践に関する考察を行う。

In the age of COVID-19 pandemic, it is difficult to hold academic events such as academic societies and symposiums where researchers gather, and many attempts are being made online. The advantages of online events are that they can participate in situations where the risk of infection is low, and that it is possible to discuss with participants who had previously had difficulty attending due to spatial and time constraints. On the other hand, the issue is how to share and discuss the issues and current situation that were conducted by directly interacting and experiencing.

Presenters held "Academic Camp 2020 in Oshu City" online on July 10th (Sat) and 11th (Sun), 2020, for multifaceted and interdisciplinary discussions on the preservation, succession, and utilization of local academic materials. In this presentation, we will consider the practice of academic events in which participants share issues and current situations and discuss with each other remotely, focusing on "online tour" in academic camp 2020.

キーワード: 研究集会, コロナ禍, オンライン学術イベント, 学術資料, 議論

Research meeting, COVID-19 pandemic, Online academic event, Academic material, Discussion 


\section{1 はじめに}

コロナ禍の現在, 学会, シンポジウム などの学術イベントは現地に研究者を集 めて開催することが困難な状況にある.

多くは中止，もしくはオンライン上の試 みがなされている，オンライン開催の利 点として，2点があげられる.

まず，感染リスクが低い状態で参加で きる点である。コロナ禍では主催者側, 参加者側は感染対策を講じることが重要 である.オンラインは双方にとってリス クのない開催・参加が可能になる.

2 点目に，今まで空間的・時間的制約で 来られなかった参加者との議論が可能に なった点である，多角的な議論が必要な 研究集会において今まで接することが少 なかった参加者との議論は重要である. また，移動時間を考慮する必要がないた め, 今まで参加しや寸かった人もより多 くの議論の場を得ることとなる.

一方，直接交流し，体験することで行 つていた現状の共有や議論をどう行うか が課題となっている．オンラインでの議 論はコロナ禍を機に積極的に行われたた め，その手法は模索されている状況であ る.さらに従来は現地で実際に見学する 巡見にて研究者が地域に集まることで直 接現状を認識し，交流してきたが，コロ ナ禍では巡見は困難な状態にある。この ような現状において，オンライン上でも 課題をより現実的に共有する手法の検討 が必要である。

以上をふまえ, 本論では「学術野営 2020 in 奥州市」(以下, 学術野営 2020）のオンライン巡見を中心に，遠隔 で参加者同士が課題や現状を共有し議論 を行う学術イベントの実践について考察
する．本論はオンライン学術イベントを 新たな議論の場としてより有効なものと することを目的とする。学術野営2020は 合同会社AMANE，国立歴史民俗博物館 [1], 奥州市教育委員会, えさし郷土文化 館，金沢大学高田良宏氏科研 [2] が共催と なり，2020年7月11日（土），12日（日） に岩手県奥州市にて行われた。

\section{2 学術野営 2020 in 奥州市}

\section{1 開催概要}

「学術野営」は昨年から開催され, 地 域にある学術資料について多様な分野の 参加者が自発的に議論し, 現状・課題を 共有することを重視している $[3]$.

2020年は岩手県奥州市にて行われ，総 勢70名ほどが参加した。奥州市，国立歴 史民俗博物館では一部の参加者が集ま り，中継された．地震などの大規模災害 (有事) と過疎化・人口減少（平時）に よる資料消失と資料の活用，奥州市の史 資料の現状と課題，コロナ禍における資 料保存・活用について議論がされた。

1日目は，まず奥州市のセッションとコ ロナ禍の資料保存についてのセッション が行われた。その後参加者は三つの

「座」に分かれ，それぞれ司会者となる 「座主」が話題提供者とともに発表・議 論を行った。「壱ノ座」は川内淳史氏 （東北大学災害科学研究所）が座主とな り有事の資料消失について，「武ノ座」 では山内利秋氏（九州保健福祉大学）が 座主となり日常的な資料消失について, そして「参ノ座」では原嶋亮輔氏（root design office）が座主となり学術資料の 活用について議論した。座ごとの議論の あとは全体討論とし，日中の議論の総括 
および今後に向けた意見を交わした，2日 目の巡見は2.2にて詳細を述べる.

それぞれの議論はSNSにてハッシュタグ をつけて随時発信することで可視化し， 参加者が他の座の議論を確認しながら座 同士を行き来できるようにした.

\section{2 オンライン巡見}

遠隔で地域の学術資料の現状を共有す るために, 学術野営2020では岩手県奥州 市の牛の博物館, 後藤新平記念館, えさ し郷土文化館の3館を巡る「オンライン巡 見」を実施した。本項では, 撮影, 編 集，当日の実施について述べる.

まず，動画の撮影である．撮影は6月 22 日（月）に実施した。聞き手が学芸員か ら解説を受け，質問をする様子を2台のカ メラで撮影した。1台は解説する学芸員 を，もう1台は解説されている資料を中心 に映した，撮影時間は，各館1時間半〜2 時間ほどである。

次に動画の編集・アップロードである. 編集は映像の乱れをカットすること，2台 のカメラの映像を 1 つ画面にあわせるこ とを行った。編集を終えた動画は動画投 稿サイトにアップロードし，URLを知って いる者のみが閲覧できる状態で公開し た。また，動画がそれぞれ長時間に及ぶ ため, 目次を作成した。

当日は学芸員とともに画面共有で動画を 解説した. 副音声のようにリアルタイム で学芸員が解説を加えることで, 参加者 の質問にもその都度動画を停止して説明 が可能である。また，実際の資料を持ち 寄って解説する機会を設けた. 資料は事 前に募集し, 今回は関東大震災, 災害, 検疫関係の資料が希望としてあがった。 オンライン巡見は上記のような準備によ
って実施されたが，それらには奥州市と 各館の協力が不可欠である.

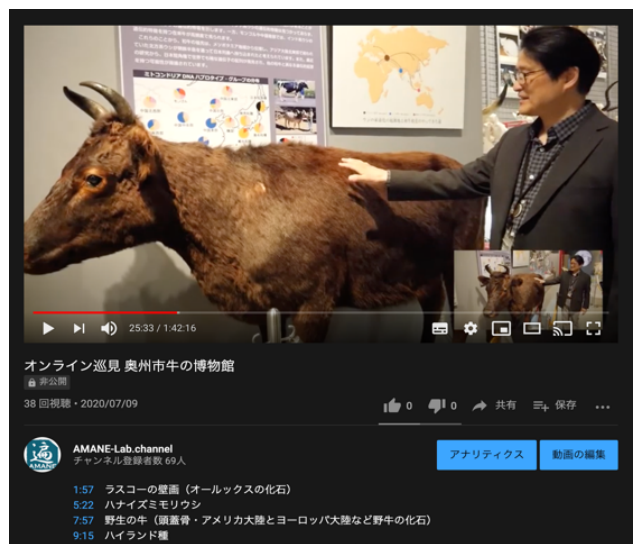

図 1 動画サイトにのせられたオンライン巡 見の動画. 説明欄に書かれた目次をクリッ ク寸ることでスキップできる.

\section{3 成果}

本項ではオンライン巡見から，利点と 改善点を見ていく.

利点は，資料についての情報を多くで きることである．撮影時は時間をかけて 解説ができ, 当日は基本の展示解説に加 え, 参加者に応じた情報を追加すること が可能である。また，カメラでの撮影は 普段展示室での見学では見られない視点 から資料を見せることができる。一方， 情報量が多いため，聞く側はその情報を 取捨選択する必要がある。そのため, 目 次の作成など聞く側が気になる点を選び やすい手段を講じることが重要である.

改善点として、発言・チャットによる 質問や議論にて，発言者の偏りや司会者 によるチャットの見逃しが見られた。発 言の有無の偏りはオフラインの議論でも あり得ることである。しかし，オンライ ン上では人数も多く参加者同士の顔が見 えないため，お互いの所属・分野などを 把握しづらい，そのため司会者による議 論の進行が中心になり, 負担が増え, 発 言の有無の偏りが司会者・主催者の人間 
関係に依存しやすかったと考えられる.

また，巡見の順序も考える必要があ る. それぞれ1時間半〜2時間の動画であ るため, 終盤にかけて聞く側・解説側が 集中力を維持することが難しい，今回は 牛の博物館, 後藤新平記念館, えさし郷 土文化館の順で行ったが，郷土の歴史全 般を取り扱うえさし郷土文化館の解説を 最初に行ったうえで他の2館の解説を行う 方がわかりや寸かった。

以上のことから, オンライン巡見は多 くの情報を伝えられる一方，聞きやすく する工夫が必要である. 議論では, 司会 者の進行が重要となるが，大人数の場合 は参加者を把握しづらい，その結果，司 会者の負担が増え，発言者が現実の人間 関係に依存する可能性がある。また、豊 富な情報を伝えられるオンライン巡見の 実施には，自治体・館側の協力を得た上 での事前の準備が非常に重要である。そ れらの関倸性の構築にはオンラインだけ でなくオフラインでの密なコミュニケー ションが不可欠である.

\section{3 考察}

本章では巡見をもとにオンライン学術 イベントの考察を行う. オンライン学術 イベントでは, 特に(1)参加者による積極 的な議論が生じにくい，(2)事前準備・関 係の構築, が重要である.

(1)について述べる. 学術野営2020で は, 議論は発言の他にチャットの意見を 司会者が拾い，発言を促寸方式が多かっ た. 司会者は進行と並行してチャットを 確認することになり，チャットを見逃す ことがある.オンラインでは司会者に負 担が増加するため, 発言の有無の偏りが
司会者・主催者の人間関係に依存しやす い. 数人が分担して議論を進行していく 対策が必要であり, 加えてオンライン上 でのコミュニティを今後どのように形成 していくかが課題となる.

(2)では，従来のイベントに比べ遠隔で 伝えるための準備が必要になってくる. その準備には，機材のほか現地に行き， 関係者と密に交流することになる。ま た, 注意喚起や要望募集など参加者との コミュニケーションも重要となった.

\section{4 おわりに}

本論では，遠隔で参加者同士が課題や 現状を共有し議論を行う学術イベントの 実践について述べてきた.オンライン学 術イベントは今までよりも多くの人が安 全に参加することが可能になった。一 方，コロナ禍以前に構成されてきた関倸 に依存しや寸く, オフライン下での事前 準備に支えられている. 実践的な議論と 課題共有を行うためには，オフラインの 役割を再認識し, 遠隔でのコミュニティ 形成について考える必要がある.

\section{注記および参考文献}

[1]国立歴史民俗博物館「総合資料学の創 成事業」, 人間文化研究機構「歴史文化 資料 保全の大学・共同利用機関ネットワ 一ク事業」。

[2] 挑戦的研究(萌芽)18K18525, 基盤研究 (B) $20 \mathrm{H} 01382$.

[3] 小川歩美; 堀井美里; 堀井洋; 川邊咲子; 後藤真; 高田良宏「学術資料の保存・継承 をテーマとした研究集会「学術野営2019 in 能登半島」に関する報告」, 情報知識 学会, Vol. 29, No. 4, pp. 330-333, 2019. 